\title{
Ethnic Studies \\ and Multiculturalism in Canada
}

By

J. Donald Wilson

University of British Columbia

Unlike the nordic countries, which are distinguished by their cultural and ethnic homogeneity, Canada is culturally and ethnically a pluralistic nation. Although united politically over a century ago, the model for Canadian nationhood resembled more closely that of the British Empire rather than that of her nearest neighbour, the United States. Since the days of imperial expansion and Catholic Emancipation, the British pattern meant not something monolithic, Protestant and Anglo-Celtic, but a number of things more diversified. His/Her Britannic Majesty, besides being head of the Church of England, was after all ruler of millions of Roman Catholic, Buddhist and Hindu subjects. Moreover, thousands of languages and dialects were spoken throughout the British Empire, and at least as many ways of life were to be found. This was the model for Canada, not the secure and confident uniformity of the American identity. Confederation made clear an important social reality of Canadian life: there was, is and can be no single exclusive definition of the Canadian identity. To try to impose a single, uniform definition fosters disunity. That is the lesson of Canadian history.

This diversity is pointed up in a private letter written by the German-Canadian poet Walter Bauer in 1976 where he wrote: "One of the outstanding qualities of this country [Canada] has been its openness to the world and its recognition of quality regardless of nationality. It could be a model in many respects, but it is quite possible that it will not recognize its chances and fritter away its possibilities." 1

Are there any indications that Canada will indeed become the model Bauer anticipated, that we will recognize our chances and 
not hitter them away? One convenient way to assess. our situation might be to draw some comparisons between Finland and Canada both roday and yesterday.

Canadians, like Finns, often lament being "on the periphery," so close to and yet so far from where the action really is. We both have large and powerful neighbours. Interestingly, although I detected the same sentiment in Finland, the metropole for the average Finn was not Moscow, but, as here, New York and Hollywood. I never once saw a windbreaker extolling the virtues of the Moscow Dynamos, but I saw many supporting the New York Rangers and the Philadelphia Flyers - even the Winnipeg Jets. Likewise, in the summer in downtown Helsinki one sees youngsters wearing $\mathrm{T}$-shirts singing the praises of Harvard and Villanova, never Leningrad University.

But being on the periphery has its advantages as well as its disadvantages. While our society may be innocent of political prisons, civil war, and a Charter '77 - or as Earle Birney has noted, "We are haunted by a lack of ghosts" - this insulation from the worst ordeals of history leaves us free to affirm the desire for and to work towards a decent, more just society. As Walter Bauer has written:

The sun here must be a different sun

From the one under which I used to live.

The sun here has seen forests and rivers,

The long crawl of primeval ages,

And then the slow invasion of the stillness by voices -

Not the end of cities burning to ashes like useless toys,

Not the flames in which history becomes timber,

Not the imprisonment of whole nations,

Not the long treks of undesirables staggering into limbo,

Not the camps like stains no acid can ever remove.

The sun here has seen nothing, nothing at all. ${ }^{2}$

Of course, Finland unlike Canada is one of those countries whose sun has seen a great deal of suffering throughout its history, particularly in this century with a bitter civil war and foreign invasion to contend with.

There are, however, other interesting comparisons to be made between these two countries on the periphery. Primary to our common experience, I think, is the fact that we are both northern nations and have been subject to varying degrees of influences Erom imperial powers. For almost 400 years Canada has been the object of imperial conquest. To the imperial metropolis our country has 
been a source of exploitation for the advantage and prestige of the powerful elsewhere - in Versailles, in London, in New York, and Washington. Finland for its part was subject to the Swedish crown for 600 years and then Imperial Russia for a further 110 years. And, since 1944, Finnish independence has been qualified by an enforced friendly relationship with Moscow.

Another similarity lies in the fact that Canada like Finland is a bilingual nation. That circumstance has now been firmly established in law and practice in both countries. The overwhelming ethnic homogeneity of Finland, however, contrasts markedly with the pluralism of Canada. From the beginning Canada was held to consist of two societies, each of which had its own values, traditions, life styles, and language. One was French-speaking, Catholic, and with some qualifications, agrarian and feudal; the other was English-speaking, Protestant, commercially-minded, and conservatively liberal in its view of society. ${ }^{3}$ Agreement on fundamentals was difficult. The creation of an ideal national type in which all Canadians could see something of themselves, and which they could all strive to emulate, was impossible. The national preoccupation came to be with differences, not similarities, with creating a nation out of culturally disparate groups, not with establishing cultural uniformity.

Thus when in the 1860's the issue of Confederation of the colonies of British North America arose, no one anticipated that this task would be performed by imposing uniformity on the diverse peoples and regions of the area. The various colonies of British North America with their unique historical development, their different religious denominations, and their different nationalities could not have been homogenized culturally as they were joined politically. The peculiarities of ianguage, creed, and regional indentity had to be maintained. Diversity was a force too powerful to be exorcised. Thus, neither then nor now could Canadians expect to have the same sort of national identity as the Americans, the French, or the Finns. The centrifugal forces inherent in our geography, history, and sources of immigration make diversity too powerful to overcome. Instead of continually searching for some overarching national identity on the model of the European or American concepts of national culture, Canadians were always better advised to come to grips with their regional, ethnic and class identities. ${ }^{4}$

Since, October, 1971 the pluralistic and multicultural nature of Canada has been once more officially reasserted. In announcing 
the policy, former prime minister Pierre Trudeau referred to Canada as a multicultural society in a bilingual state. ${ }^{5}$ The policy of multiculturalism has given great impetus to the study of ethnicity in Canada, while at the same time it should be noted that ethnic studies is primarily concerned with understanding Canadian social reality and not with promoting or opposing ethnic diversity. In May, 1971, for example, the Canadian Ethnic Studies Association came into being with this very purpose in mind - namely, to study Canada's social reality. It soon launched a semiannual journal of its own called Canadian Ethnic Studies and a quarterly newsletter called the CESA Bulletin.

The federal department of Secretary of State has also played an important role in promoting ethnic studies. Some years ago it launched its very important ethnic histories of Canada series entitled "Generations: A History of Canada's Peoples". Several titles have already appeared and some two dozen more are in preparation.

Other indications of the current interest in ethnic studies can be briefly cited. The archival acquisition policies of Canada's various public and university archives have shifted from showing virtually no interest to a deep concern to preserve published, handwritten and oral documentation relating to this nation's ethnic heritage. Special note should also be made of the work of the Multicultural History Society of Ontario. This organization is not only collecting archival material, but also publishes a fine periodical called Polyphony, produces numerous Occasional Papers reporting aspects of the history of various ethnic groups, stages conferences of international note, and maintains contact with research institutes aboard, such as the Institute for Migration in Turku.

It is now almost a decade since Rudolph Vecoli wrote of ethnicity as the "neglected dimension" of American history. ${ }^{6}$ His indictment of American historians might also be applied to Canadian historians of the time: "That the history of a society the distinctive attribute of which has been its racial, cultural, linguistic, and religious pluralism should have been written for the most part from an Anglo-American monistic perspective is indeed a paradox." " But what was true then is no longer so either in the United States or Canada. In my own field alone, history, the output of articles and books pertaining to ethnic studies has been quite remarkable in the past five years. The ethnic histories series has alredy been mentioned, but works the quality of Don Avery's Dangerous Foreigners 
(Toronto, 1979) and Peter Ward's White Canada Forever (Montreal, 1978) also bear out my point.

The spread of historical studies owes much to borrowing the analytical tools of the other social sciences. Ethnic history has now become part of a broadly based assault on the social history of Canada. Recent work in Canadian working class history, urban history and educational history points to the need to link up with ethnic history in order to provide a more complete and satisfactory analysis of the Canadian past. ${ }^{8}$ More work is still needed to link elite and popular thought among Canada's peoples. As J.M. Bumsted has recently pointed out with reference to the study of Canadian intellectual history today, it is "the constellations of unsystematic mental equipment (l'outillage mental) upon which most action is based" that is important to examine. "It no longer matters," Bumsted continued, "that we [Canadians] have not produced a Plato, Hobbes, or Adam Smith, or that our ideas have been derivative. The mentalités are part of the Canadian experience, and hence worth studying on their own merits." 9 The results of such an approach to our intellectual past should be an integrated cultural history as opposed to an elite intellectual history.

To assess where we might go in Canadian ethnic history, it might be wise first off to see where we have been. There have been to date two main stages in the writing of Canadian ethnic history. The first was the filiopietistic stage where the history consisted essentially of lists of individual immigrant's accomplishments. Areas of controversy, intra-group problems and generational friction tended to be glossed over. ${ }^{10}$ The second stage - one we are still in - viewed immigrant settlers in Canada from the perspective of assimilation, that is, essentially from the perspective of the host society. It was the story of the decline of traditional cultures among immigrant peoples and their transformation by the Canadian environment. While this approach marked a distinct improvement over the filiopietistic stage, it still did immigrants and their descendants a disservice, for it denied them a positive historical experience. Such accounts are not "the history of creating communities, families and valuesystems with some coherent and continuous relationship to the past. Rather it is a history of negation, disorganization and passive re-molding of the compelling exigencies of [Canadian] society."11

The host society perspective has fostered an image of the immigrant as someone lacking in resilience and tenacity, quickly cut adrift from his cultural inheritance, and pulled inexorably into the 
assimilationist society of his newly adopted country. ${ }^{12}$ If instead the ethnic perspective were adopted, that is, viewing the immigrant from his own perspective, the operative assumption would be reversed. Those who uprooted themselves from their countries of origin, who overcame so many hardships and uncertainties in travelling to the new world, and who eventually established themselves here despite the host country's unfamiliarity and often hostility - these people must have had both courage and initiative in large measure. The work of the Danish historian Kristian Hvidt provides a starting point in this regard, and it is worthwhile to restate one of the provocative questions he asked about Swedish emigration:

Was it, gcnerally speaking, those who had the lowest intelligence who emigrated to America and Australia, those who could not hold their own in Europe - black sheep who were perhaps forced to resort to illegal measures in order to survive in the competition? ... A comparison of those Swedes, rural as well as urban people, who emigrated later on, with those who remained in Sweden, reveals that everywhere, irrespective of the country chosen, emigrants gcnerally made higher marks than the rest of the population. They were bright in school, had a wider picture of the world, and were the kind of persons to whom it would occur to leave their habitual surroundings... the actual emigrants abroad seem to have had the highest intellectual level. ${ }^{13}$

Alan Richardson in his study of British migration to Australia likewise concluded that "the likelihood of actual emigration is increased for the person who has an extroverted tendency to solve his problems through vigorous action."14

Similarly, in discussing the immigrant settler, the picture of the rootless, dislocated immigrant needs to be challenged, what one source has referred to as "the picture of social randomness." 15 Ethnic newspapers and mutual benefit societies helped to give recent immigrants a sense of belonging and to reduce the anxiety about not knowing where one might be living from month to month. ${ }^{16}$ In immigrant churches, temperance societies, cooperatives and socialist clubs "old customs and old ideas were fired and recast, sometimes in original and sometimes in traditional molds. The overall result, however, was a new institutional and ideological pattern, adjusted in numerous ways to the social and economic order in which the newcomers had at first been strangers." 17

Another stereotype also needs to be questioned, namely that of the fawning, subservient immigrant. Italians, for example, were not always scabs. Sometimes they refused to be strikebreakers and actually joined the ranks of the very strikers they were supposed to replace, as in the freight handlers' strike in Fort William in 1909.18 
Likewise, many Finnish socialists showed their independence by continuing to support left-wing political parties, such as the Social Democratic Party of Canada and the Communist Party of Canada, even though such support brought them under suspicion. ${ }^{10}$ Finally, one thinks of the Ukrainians' determination in Western Canada to keep their language alive in the face of determined angloCanadian assimilation tactics through the schools. ${ }^{20}$ These are not the passive individuals of the Handlin stereotype.

When the study of immigration and ethnicity centres on the question of how immigrants were absorbed into on-going Canadian society, something else is lost, namely the recognition of how profoundly the course of Canadian social history has been influenced by mass immigration. This movement of European and Asian peasants to Canada around the turn of the century and after World War I constituted a major phase in the making of an industrial working class in Canada. ${ }^{21}$ The mines and mills of industrial Canada formed a new world of work and work-discipline ${ }^{22}$ as strange to native-born Canadians as it was to newcomers. The native-born as well as the immigrant learned to contend with this world through recourse to unions, political parties, family solidarity, leisure-time activities, heavy drinking, etc. There were no distinctively "Canadian" institutions in place to contend with this new world. Thus, in a real sense, immigrants were not assimilated into an older Canadian social and cultural order; rather they were a major force in creating a new and radically different one. This is one of the main messages of Don Avery's book.

Not only did these ethnic working-class communities give rise to new institutions, but new meanings were also assigned to older institutions. The public scliool is a good example of this. In the process of being assigned the major task of assimilating immigrant children, the public school changed dramatically during this era. Numerous bitter language questions erupted in the prairie provinces and Ontario. ${ }^{23}$ The public school teacher came to be seen as a missionary, or as J.T.M. Anderson remarked, "the teacher is one of the most important - if not the most important - element in racial assimilation". . . leading to the preparation of "the pure gold of Canadian citizenship." 24 Through its efforts in the area of public health never before assigned to the school, such as teeth and eye examinations, vaccination, and overall cleanliness, the public school became a major vehicle of social policy. ${ }^{25}$ In brief, the public school was fundamentally altered. Again, these examples merely 
serve to underline the active and creative role played by immigrants and their children in Canadian social history.

As Clarke Chambers has correctly noted with respect to the writing of American history - "If consensus and continuity were the prevailing perceptions (and precepts) of the 1950's, a sense of diversity, conflict, and discontinuity now moves us" 26 - much the same is true of Canadian historiography. The new social history has taken firm hold in Canada under the impact of the sophisticated approaches current in Britain, France and the United States. Almost every aspect of society is coming under the social historian's scrutiny, including immigration and ethnic history. "Canadian society," as one source says, "was created by a continuing barrage of fragments which constantly modified the social structure and intermittently provided new versions of social good." ${ }^{27}$ To date, no grand syntheses have occurred, ${ }^{28}$ but when they do they will certainly take into account the outpouring of books and articles about ethnic history already published and which will continue to appear.

NOTES

1 F.W. Watt, "A Different Son: Walter Bauer's Canadian Poetry," Canadian Forum, L1X, 692 (Sept. 1979), p. 22.

2 Walter Bauer, "The Sun Here," A Different Sun, trans, by Henry Beissel (Toronto, 1976), p. 10.

3 See A.R.M. Lower, "Two Ways of Life:The Primary Antithesis of Canadian History," Canadian Historical Association, Report, 1943, pp. 5-18, and Kenneth D. McRae, "The Structure of Canadian History," in Louis Hartz (ed.), The Founding of New Societies (New York, 1964), pp. 219-274.

4 The term "limited identities" in this sense was first used by Ramsay Cook in "Canadian Centennial Celebrations," International Fournal XXII (Autumn,. 1967), p. 663.

5 Prime Minister Trudeau's actual words in announcing the policy were: "multiculturalism within a bilingual framework." Canadian News Facts, $V$ (Oct. 19, 1971), p. 713.

6 RudolfJ. Vecoli, "Ethnicity: A Neglected Dimension of American History,"' American Studies in Scandinavia, no. 4 (Summer, 1970), p. 9.

7 Ibid., p. 10.

8 Representative samples of some of this work are: A. Ross McCormack, Reformers, Rebels, and Revolutionaries: The Western Canadian Radical Movement, 1899-1919. (Toronto, 1977); David J. Bercuson, Fools and Wise men: The Rise and Fall of the One Big Union (Toronto: McGraw-Hill Ryerson, 1978); Alan J.F. Artibise, Winnipeg = A Social History of Urban Growth, 1874-1914 (Montreal,. 1975); Cornelius J. Jaenen, "The Manitoba School Question, An Ethnic Interpretation," in M.L. Kovacs (ed.), Ethnic Canadians : Culture and Education (Regina, 1978), pp. 317-331; Neil G. McDonald, "David J. Goggin: Pro- 
rnoter of National Schools," in D.C. Jones, N.M. Sheehan and R.M. Stamp (eds.), Shaping the Schools of the Canadian West (Calgary, 1979), pp. 14-28,

9 J.M. Bumstead, "Canadian Intellectual History and the 'Buzzing of Factu. ality,' "9 Acadiensis, VII, 1(Autumn 1977), p. 115-116.

10 Typical of this type of book was the series entitled Canada Ethnica funded by Canada's Centennial Commission in conjunction with the celebration of the hundredth anniversary of Confederationin 1967. The authors were individual involved in the life of ethnic organizations. W.J. Lindal, The Icelanders ir Canada; Ludwick Kos-Rabiewicz Zubliowski, The Poles in Canada; A. Spada The Italians in Canada; P.R. Gaida, The Lithuanians in Canada; 01' ha Woycen. ko, The Ukrainians in Canada.

11 Michael M. Passi, "Review Essay: Myth as History, History as Myth: Family and Church Among Italian Canadians," Journal of Ethnic Studies, 2 (Summer, 1975), p. 97.

12 This view is associated with Oscar Handlin, The Uprooted (2nd edition, Boston, 1973).

13 Kristian Hvidt, Flight to America: The Social Background of 300,000 Danish Emigrants (New York, 1975), pp. 108-109. For similar conclusions, see Kjel. Soderberg, "Personal Characteristics and Selective Migration," in Bc Kronborg, Thomas Nilsson and Andres Svalestuen (eds.), Nordic Population Mobility : Comparative Studies of Selected Parishes in the Nordic Countries, 1850-1900 (Oslo, 1977), especially pp. 127-135, 148-149.

14 Alan Richardson, British Immigrants and Australia: A Psychosocial Inquir (Canberra, 1974), p. 139.

15 R.G. Hann, G.S. Kealey, L. Kealey and Peter Warrian (eds.), Primary Source. in Canadian Working Class History (Kitchener, 1974), p. 17.

16 See special issue of Polyphony (the bulletin of the Multicultural History Society of Ontario) devoted to the mutual benefit society, II, 1 (Winter, 1979).

17 Timothy L. Smith. "Parochial Education and American Culture, "' in Paul Nash (ed.), History and Education (New York, 1970), pp. 203, 205. For Canada see the work of Jorgen Dahlie: "Learning on the Frontier: Scandinavian Immigrants and Education in Western Canada." Canadian and International Education, 1, 2 (December, 1972), pp. 56-66; "The Japanese in B.C.: Lost Oppor. tunity: Some Aspects of the Education of Minorities," B.C. Studies, No. 8 (Winter, 1970-71), pp. 3-16, and also the recently completed thesis of Antonio Pucci in which he details the role of the local Italian mutual benefit society in Fort William's East End in serving the Italian immigrant both a a shelter against the battering of a sometimes hostile host society and also as an effective means of easing the recent arrival into the ways of Canadian society. "The Italian Community in Fort William's East End in the Early Twentieth Century" (M.A. thesis, Lakehead University, 1977) chapter 5 Also published in Polyphony II, 1 (Winter, 1979), pp. 19-24.

18 Ibid, pp. 167-183.

19 Edward Iaine, "Finnish Canadian Radicalism and Canadian Politics: The First Forty Years, 1900-1940." Paper presented at the Canadian Ethnic Studies Association Biennial Conference, Vancouver, October 12, 1979.

20 Cornelius J. Jaenen, "Ruthenian Schools in Western Canada," in Shaping the Schools of the Canadian West, pp. 39-58.

21 Donald Avery, 'Dangerous Foreigners' = European Immigrant Workers and Laboun Radicalism in Canada, 1896 - 1932. (Toronto, 1979); David J. Bercuson, "Lab. our Radicalism and the Western Industrial Frontier: 1897-1919," Canadiar Historical Review, LVIII, 2 (June 1977), pp. 154-175.

22 Herbert G. Gutman, "Work, Culture and Society in Industrializing America, 1815-1919," American Historical Review, 78 (1973), pp. 530-587. 
23 Manoly R. Lupul, "Educational Crises in the New Dominion to 1917," in J.D. Wilson, R.M. Stamp and L.P. Audet (eds.), Canadian Education: A History (Scarborough, 1970), pp. 266-289.

24 J.T.M. Anderson, The Education of the Nere Canadian (Toronto, 1918), pp. $231,114$.

25 Neil Sutherland, Children in English-Canadian Society: Framing the TwentiethCentury Consensus (Toronto, 1976), especially Part IT.

26 Clarke A. Chambers, "Historians and Ethnicity: The New Social History," in Michael Karni, Matti Kamps and Douglas Olilla, Jr. (eds.), The Finnish Experience in the Western Great Lakes Region: New Perspectives (Turku, 1975), p. 11.

27 Primaty Sources in Canadian Working Class History, p. 15.

28 Michael S. Cross, "Recent Writings in Social History," in theme issue "Reinterpreting Canada's Past." History and Social Science Teacher, XIV, 3 (Spring, 1979), pp. 155-164. 